\title{
What Drives Ambition? Personality, Self-Perceived Leadership Potential, and the "Desire to Be Your Own Boss"
}

\author{
Luke Treglown1, Ian MacRae1, Adrian Furnham ${ }^{2 *}$ \\ ${ }^{1}$ Research Department of Clinical, Educational and Health Psychology, University College London, London, UK \\ ${ }^{2}$ Norwegian Business School (BI), Nydalsveien, Oslo, Norway \\ Email: *a.furnham@ucl.ac.uk
}

How to cite this paper: Treglown, L., MacRae, I., \& Furnham, A. (2020). What Drives Ambition? Personality, Self-Perceived Leadership Potential, and the "Desire to Be Your Own Boss”. Psychology, 11, 624-635. https://doi.org/10.4236/psych.2020.114042

Received: March 20, 2020

Accepted: April 24, 2020

Published: April 27, 2020

Copyright () 2020 by author(s) and Scientific Research Publishing Inc. This work is licensed under the Creative Commons Attribution International License (CC BY 4.0).

http://creativecommons.org/licenses/by/4.0/ (c) (i) Open Access

\begin{abstract}
This study focuses on the correlates of an individual's rating of their leadership potential. 1194 adults completed a six-factor High Potential work-related questionnaire and they also self-rated their leadership potential as well as their actual desire to become their own boss. Neither age nor sex was related to the two dependent variables, but nearly all the traits were. Stepwise regressions showed Competitiveness, Risk Approach and Conscientiousness were particularly related to self-related leadership potential. Three traits, namely Competitiveness, Risk Approach and Curiosity were related to the desire to become their own boss which accounted for $16 \%$ of the variance. SEM showed Conscientiousness, Curiosity, Risk Approach, Ambiguity Acceptance, and Competitiveness were significant positive predictors of self-rated Leadership Potential $\left(\mathrm{R}^{2}=.33\right)$. Similarly, Curiosity, Risk Approach, Competitiveness, and Leadership Potential were significant positive predictors of participants' desire to be their own boss, whilst Adjustment was a negative predictor. Implications and limitations are acknowledged.
\end{abstract}

\section{Keywords}

Potential, Leadership, Competitiveness, Conscientiousness, Curiosity

\section{Introduction}

What sort of people want to become their own boss and organisational leaders? What are the personality correlates of self-perceived leadership ability and skill? This study examines demographic and personality correlates of the above two questions.

Pendleton and Furnham (2017) indicated that there are essentially three types 
of jobs: technical, supervisory and strategic. Often technical experts are promoted into supervisory/managerial jobs that they neither enjoy nor thrive in. The same is true for those promoted to strategic or senior leadership roles. Whereas most people seek recognition and reward many are not particularly eager to take up leadership roles. In this study we shall examine correlates of this desire. There is a comparative paucity in the area.

\section{Self-Assessed Abilities}

There is an extensive literature on self-related abilities including intelligence, emotional intelligence and attractiveness (Furnham, 2001, 2018). The results for self-estimated IQ showed that first, males of all ages and backgrounds tend to estimate their (overall) general intelligence about 5 to 15 IQ points higher than do females. Always those estimates are above average and usually around one standard deviation above the norm.

Second, when judging "multiple intelligences" males estimate their spatial and mathematical (numerical) intelligence higher but emotional intelligence lower than do females. On some multiple intelligences (verbal, musical, body-kinaesthetic) there is little or no sex difference.

Third, sex differences are cross-culturally consistent. Differences seem to lie in cultural definitions of intelligence as well as norms associated with humility and hubris. Forth, the correlation between self-estimated and test generated IQ is positive and low in the range of $r=.2$ to $r=.5$ suggesting that you cannot use test scores as proxy for actual scores.

Fifth, with regard to outliers, those who score high on IQ but give low self-estimates tend nearly always to be female, while those with the opposite pattern (high estimates, low scores) tend to be male.

One question we ask in this paper is whether self-estimates of leadership ability are the same as those of self-rated intelligence as noted above. There many commercial leadership self-assessment tools but not appear to be many studies on self-rated leadership ability though it may be that early learning experience has convinced some people that they "have what it takes". Those studies that do exist show the above pattern: males tend to self-rate higher than females, and correlations between self-rated and actual ability are positive but modest (Archer et al., 2016; Moore \& Rudd, 2005). However, it is also clear that some people, though they might believe they have leadership ability, do not seek out leadership positions because of the problems that come with the role (Pendleton \& Furnham, 2017). Hence, there is the question of the desire to "be one's own boss". Whilst it is true that one could be one's own boss by working alone or as a consultant, most people understand this to mean being a leader of a group or organisation.

In this study we are interested in demographic and personality trait correlates of these two variables: self-rated leadership ability and desire to be one's own boss. 


\section{High Potential Traits Inventory}

In this study we used the HPTI which was developed to measure personality at work. There is significant overlap with the Big Five (FFM) on three traits but three additional traits, shown to be related to success in a variety of jobs. The first, most well researched trait is Conscientiousness characterised by self-discipline, organisation and ability to moderate one's own impulses (Costa \& McCrae, 1992; Wille et al., 2013). Many studies have shown it to be a trait consistently related to success in education and work (Furnham, 2018; Judge et al., 1997). Barrick et al.'s (2001) meta-analysis found Conscientiousness was a predictor of job success across all jobs and all measures of success.

Adjustment (low Neuroticism) is the adaptive end of the FFM Neuroticism trait (Costa \& McCrae, 1992; Wille et al., 2013). It is characterised by emotional resilience to stressors, positive affect and mood stability and regulation. Adjustment has been shown to related to various indices of higher work performance (Judge \& Locke, 1993). Barrick et al.'s (2001) meta-analysis found higher adjustment was associated with improved performance and better teamwork in many occupations.

Curiosity (Openness) is characterised by an interest in new ideas, experiences and situations. Openness at work encompasses new ways of completing tasks, new business ideas, and interest in colleagues with different opinions. Judge et al. (1999) found Openness was moderately associated with job satisfaction, occupational status and extrinsic career success. Van der Linden et al. (2010) confirmed Openness was associated with improved performance and learning outcomes. Barrick et al.'s (2001) meta-analysis of personality and job performance found Openness was moderately associated with training proficiency but was less related to performance than Conscientiousness or Adjustment.

Ambiguity Acceptance, sometimes described as Ambiguity Tolerance (AT), describes how an individual or group processes and perceives unfamiliarity or incongruence (Furnham \& Ribchester, 1995). Those who are tolerant of ambiguity perform well in new or uncertain situations, adapt when duties or objectives are unclear, and are able to learn in unpredictable times or environments. McCall (1997) suggested from extensive qualitative evidence that adapting to ambiguity is an essential trait of High-Flyers. Herman et al. (2010) found ambiguity tolerance involved four facets: valuing diversity, challenging perspectives, unfamiliarity, and change. The ambiguity tolerance component of the High-Flying Personality Traits incorporates the four facets of AT. Those with higher ambiguity tolerance should perform better in high-level leadership positions because they have to incorporate many different sources of information and make decisions based on mixed information.

The fifth trait is Competitiveness. Wang and Netemeyer (2002) suggested that Competitiveness is a distinct trait that reflects part of McClelland's (1965) N-Ach, and the achievement component of Type A personality (Thornton et al., 2011). Trait Competitiveness focuses on the adaptive elements of Competitiveness that 
drive self-improvement, desire for individual and team success, and learning.

The final trait Courage, or approach to risk, which is the ability to combat or mitigate negative or threat-based emotions and broaden the potential range of responses. Hannah et al. (2007) suggest the courageous individual uses the positive emotion, courage, to mitigate fear of interpersonal conflict or reprisal to confront the behaviour. In an empirical study, Norton and Weiss (2009) found self-report measures of Courage predicted actual courageous responses in a fear-evoking situation. Unchecked fear restricts the potential range of responses, and typically leads to behaviours like avoidance or contrived ignorance, whereas courage is exhibited as the willingness to confront difficult situations and solve problems in spite of adversity. Therefore, Courage can be expressed in many situations including calculated risk taking, interpersonal confrontation and problem solving, or moral fortitude (Norton \& Weiss, 2009).

A number of papers have used the HPTI (Furnham \& Treglown, 2018) of which the most relevant is the study by Teodorescu, Furnham, and MacRae (2017). Their results indicated HPTI personality traits relate to subjective and objective measures of success with Conscientiousness being the strongest predictor.

Assuming that adults have, through experience, some insight into their leadership success and failure and based on the extensive literature on leadership we tested the following hypotheses:

1) Males rate their leadership ability more highly than females (H1) and would have a stronger desire to be their own boss (H2).

2) All high potential traits, particularly Competitiveness, Courage and Conscientiousness, would be positively correlated with self-rated leadership ability (H3).

3) Self-rated leadership ability would be significantly positively related to the desire to be one's own boss (H4).

\section{Method}

\subsection{Participants}

There were 1194 participants in this study, of which 679 were female and 515 were male. The mean age of this sample was 38.9 years $(S D=13.6)$. The sample was mostly from Canada $(n=688 ; 62.4 \%)$, with the rest being from the USA. Most participants spoke English as their first language ( $\mathrm{n}=1022$; 85.6\%), with Spanish being the next most frequent first language $(n=23 ; 1.9 \%) .916(76.7 \%)$ participants were in some form of full-time employment, 111 (9.3\%) were part-time employed and $74(6 \%)$ were students. The most frequently cited industries of work were Retail ( $\mathrm{n}=123 ; 10.3 \%)$, Health $(\mathrm{n}=117 ; 9.8 \%)$, and Education ( $\mathrm{n}=115 ; 9.6 \%)$, with the most frequently cited job roles being Customer Service Occupation $(\mathrm{n}=112 ; 9.4)$, Sales $(\mathrm{n}=98 ; 8.2 \%)$, and Teaching $(\mathrm{n}=99$; $8.3 \%)$. Additionally, $45.4 \%(\mathrm{n}=543)$ of participants were in a non-management position, with $12.5 \%(\mathrm{n}=149)$ being a first-line manager, $9.5 \%(\mathrm{n}=113)$ being in middle management, and $11.6 \%(n=139)$ being in some form of senior 
management.

\subsection{Measures}

High Potential Trait Indicator (HPTI) (MacRae, 2012; MacRae \& Furnham, 2014)-The HPTI is a measure of personality traits, specifically within a workplace context. It is comprised of six factors. The inventory is 78 items in length. Each trait was converted into a standardized score to allow for better comparison between traits.

\subsection{Procedure}

The data was gathered as a part of a general population norm sampling in North America by a British psychometric test publisher. The data was collected via an online platform, with participants being recruited through personal and professional networks. Participants whose response pattern was could be considered random or careless were screened out. Written and informed consent was provided by all participants before engaging in the study. Participants received feedback on their highest and lowest HPTI trait scores after completing the study. After completing the HPTI, before receiving any feedback on their scores, participants were asked to rate their self-perceived levels of "Leadership Potential" and "Desire to be your own boss" on a 0 - 100 sliding scale.

\subsection{Analysis}

The dataset was organised and cleaned using R Studio. Structural equation modelling (SEM) was conducted in the Lavaan package (Rosseel, 2012; version .5-20) of R (version 3.3.0). Based upon Kline's (2005) recommendations, the following fit indices were applied: the $\chi^{2} / \mathrm{df}$ ratio, RMSEA, Standardized Root Mean Residual (SRMR), and the Comparative fit index (CFI). An excellent fit is indicated when $\chi^{2} /$ df $<3.00$ (van Dam, 2015), RMSEA < .05 (MacCallum et al., 1996), SRMR <.08 (Hu \& Bentler, 1998), and CFI > .95 (Hooper et al., 2008).

\section{Results}

\subsection{Correlations}

Table 1 shows the correlations between participant's age, gender, HPTI scores, and self-perceived Leadership Potential and desire to be their own boss. Age was significantly positively correlated with Conscientiousness, Adjustment, Risk Approach, and Ambiguity Acceptance, but was negatively correlated with Competitiveness. Gender was significantly negatively correlated with Risk Approach and Competitiveness, indicating that males have higher levels of Risk Approach and Competitiveness than females. Age and Gender were not significantly correlated with self-perceived Leadership Potential. However, Gender was significantly negatively correlated with participants' desire to be their own boss, indicating male participants have a greater desire to be their own boss compared to female participants. 
Table 1. Correlations between demographics, HPTI, self-perceived leadership potential and desire to be their own boss.

\begin{tabular}{|c|c|c|c|c|c|c|c|c|c|}
\hline & Age & Gender & Conscientiousness & Adjustment & Curiosity & $\begin{array}{c}\text { Risk } \\
\text { Approach }\end{array}$ & $\begin{array}{l}\text { Ambiguity } \\
\text { Acceptance }\end{array}$ & Competitiveness & $\begin{array}{c}\text { Leadership } \\
\text { Potential }\end{array}$ \\
\hline \multicolumn{10}{|l|}{ Age } \\
\hline Gender & -.01 & & & & & & & & \\
\hline Conscientiousness & $.17^{\star * *}$ & .05 & & & & & & & \\
\hline Adjustment & $.20^{* * *}$ & .03 & $.38^{* * *}$ & & & & & & \\
\hline Curiosity & .03 & .02 & $.46^{\star \star *}$ & $.20^{\star \star \star}$ & & & & & \\
\hline Risk Approach & $.19^{* * *}$ & $-.07^{*}$ & $.56^{* * *}$ & $.45^{\star * *}$ & $.51^{* * *}$ & & & & \\
\hline $\begin{array}{l}\text { Ambiguity } \\
\text { Acceptance }\end{array}$ & $.11^{* * *}$ & .00 & $.13^{* * *}$ & $.36^{* * *}$ & $.20^{* * *}$ & $.33^{* * *}$ & & & \\
\hline Competitiveness & $-.22^{* * *}$ & $-.15^{\star * \star}$ & $.27^{\star * *}$ & $-.09^{* *}$ & $.16^{* * *}$ & $.33^{\star * *}$ & $.08^{* *}$ & & \\
\hline $\begin{array}{c}\text { Leadership } \\
\text { Potential }\end{array}$ & -.02 & -.02 & $.42^{* * *}$ & $.23^{* * *}$ & $.35^{* * *}$ & $.49^{* * *}$ & $.20^{* * *}$ & $.37^{* * *}$ & \\
\hline $\begin{array}{l}\text { Desire to be } \\
\text { Own Boss }\end{array}$ & -.05 & $-.07^{*}$ & $.22^{\star \star \star}$ & .04 & $.26^{\star \star \star}$ & $.30^{* * *}$ & $.08^{\star *}$ & $.31^{* * *}$ & $.44^{* * *}$ \\
\hline
\end{tabular}

Note: ${ }^{* * *}=p<.001 ;{ }^{* *}=p<.01{ }^{*}=p<.05$.

All six HPTI traits were significantly, positively correlated with participants' self-perceived leadership potential, with correlation coefficients ranging from .20 (Ambiguity Acceptance) to 49 (Risk Approach). Only five of the six HPTI traits were significantly correlated with participants' desire to be their own boss, with correlation coefficients ranging from .08 (Ambiguity Acceptance) to .31 (Competitiveness). Participants' self-perceived leadership potential was also significantly correlated with their desire to be their own boss.

\subsection{Regressions}

Table 2 shows the results of a hierarchical linear regression on self-perceived leadership potential. Age and Gender were entered in step 1, with neither being a significant predictor of leadership potential. The six HPTI traits were entered in step 2, which explained a total of $32.7 \%$ of the variance. Five of the six traits were significant predictors of self-perceived potential, where participants with higher levels of trait Conscientiousness, Curiosity, Risk Approach, Ambiguity Acceptance, and Competitiveness rating themselves as having greater leadership potential.

Table 3 shows a second hierarchical linear regression on participants' desire to be their own boss. In step 1, Gender was a significant negative predictor, indicating males have a greater desire to be their own boss than females. However, this step explained only $.8 \%$ of the variance and was not significant overall $(F(1$, $1193)=.454 ; p=.011)$. The six HPTI traits were entered in the second step, explaining an additional $15.1 \%$. Only three traits were significant predictors, with higher Curiosity, Risk Approach, and Competitiveness being predictive of a greater desire to be your own boss. Gender was no longer a significant predictor in the second step. Self-perceived Leadership Potential was entered in the third 
step and was a significant positive predictor, explaining an additional $8.1 \%(24 \%$ in total). Additionally, in the third step Adjustment because a significant negative predictor of participants' desire to be their own boss $(\beta=-.07, p=.041)$.

Table 2. Hierarchical regression of demographics and HPTI traits on self-perceived leadership potential.

\begin{tabular}{|c|c|c|c|}
\hline & & \multicolumn{2}{|c|}{ Leadership Potential } \\
\hline & & $\beta$ & $\mathrm{t}$ \\
\hline \multirow[t]{2}{*}{ Step 1} & Age & -.02 & -.54 \\
\hline & Gender & -.02 & -.55 \\
\hline F Score & & \multicolumn{2}{|c|}{$F(2,1191)=.30$} \\
\hline R2 & & \multicolumn{2}{|c|}{.000} \\
\hline \multirow[t]{6}{*}{ Step 2} & Conscientiousness & .17 & $5.23^{* * *}$ \\
\hline & Adjustment & .04 & 1.22 \\
\hline & Curiosity & .09 & $2.97^{\star *}$ \\
\hline & Risk Approach & .26 & $7.51^{* * *}$ \\
\hline & Ambiguity Accept & .05 & $2.02^{*}$ \\
\hline & Competitiveness & .22 & $7.68^{* * *}$ \\
\hline F Change & & \multicolumn{2}{|c|}{$F(8,1185)=95.88^{\star * \star}$} \\
\hline R2 ( $\Delta$ R2) & & \multicolumn{2}{|c|}{$.327(.327)$} \\
\hline
\end{tabular}

Note: ${ }^{* *}=p<.001 ;^{* *}=p<.01 ;^{*}=p<.05$; standardized betas reported.

Table 3. Hierarchical regression of demographics, HPTI, and leadership potential on desire to be own boss.

\begin{tabular}{|c|c|c|c|}
\hline & & \multicolumn{2}{|c|}{ Desire to Be Own Boss } \\
\hline & & $\beta$ & $\mathrm{t}$ \\
\hline \multirow[t]{2}{*}{ Step 1} & Age & -.05 & -1.83 \\
\hline & Gender & -.07 & $-2.40^{\star}$ \\
\hline F Score & & \multicolumn{2}{|c|}{$F(2,1191)=4.54$} \\
\hline $\mathrm{R} 2$ & & \multicolumn{2}{|c|}{.008} \\
\hline \multirow[t]{6}{*}{ Step 2} & Conscientiousness & .03 & .95 \\
\hline & Adjustment & -.05 & -1.57 \\
\hline & Curiosity & .13 & $4.09^{* * *}$ \\
\hline & Risk Approach & .17 & $4.45^{* * *}$ \\
\hline & Ambiguity Accept & -.01 & -.22 \\
\hline & Competitiveness & .21 & $6.64^{* * *}$ \\
\hline F Change & & \multicolumn{2}{|c|}{$F(8,1185)=39.18^{\star * *}$} \\
\hline $\mathrm{R} 2(\Delta \mathrm{R} 2)$ & & \multicolumn{2}{|c|}{$.159(.151)$} \\
\hline Step 3 & Leadership Potential & .348 & $11.28^{* * *}$ \\
\hline F Change & & \multicolumn{2}{|c|}{$F(9,1184)=127.12^{\star * *}$} \\
\hline $\mathrm{R} 2(\Delta \mathrm{R} 2)$ & & \multicolumn{2}{|c|}{$.240(.081)$} \\
\hline
\end{tabular}

Note: ${ }^{* *}=p<.001 ;{ }^{* *}=p<.01 ;^{*}=p<.05 ;$ standardized betas reported. 


\subsection{Structural Equation Model}

SEM was used to further explore the relationships between HPTI, potential, and desire to be your own boss. In particular, SEM was used to assess multivariate regression and mediation analysis. Due to the non-availability of item level data, the six HPTI items were entered as observed variables. "Leadership Potential" and "Desire to Be Own Boss" were also entered as observed variables. Non-significant questions regressions were removed in a backwards elimination style until only significant terms remained.

The results of the SEM can be seen in Figure 1. The chi-squared statistic was not significant $\left(\chi^{2}(3)=2.88, p=.411\right)$. Other fit statistics indicated that the model was an excellent fit of the data: CFI $=1.00 ; \chi / \mathrm{df}=.96$; $\mathrm{RMSEA}=.000$ (upper 95\% CI $=.048$; lower CI $=.000$ ); SRMR $=.006$.

Replicating what was seen in the regressions, Conscientiousness, Curiosity, Risk Approach, Ambiguity Acceptance, and Competitiveness were significant positive predictors of Leadership Potential $\left(\mathrm{R}^{2}=.324\right)$. Additionally, Curiosity, Risk Approach, Competitiveness, and Leadership Potential were significant positive predictors of participants' desire to be their own boss, whilst Adjustment was a negative predictor. Mediation was tested via indirect effects of HPTI on desire to be own boss in the Lavaan package. Tests of indirect effect found that both Conscientiousness $(\beta=1.73 ; p<.001)$ and Ambiguity Acceptance $(\beta=.56$; $p=.021$ ) had significant indirect effects on participants' desire to be their own boss, being fully mediated by leadership potential.

\section{Discussion}

The result of this study confirmed many, but not all hypotheses. It was surprising that there was effectively no age or sex difference on either variable, given that many studies have shown that males rate their ability higher than females and are usually eager to be their own boss. Equally, it may be expected that older people would give themselves higher ratings. One answer could be in the nature of this sample: they were mainly middle-aged, North American successful business people, many of whom had successful careers and held management/leadership roles, Cultural changes with respect to male and female roles, particularly in North America could account for the absence of sex differences. Also, most participants were middle-aged employees confident in their roles and knowledgeable about their leadership talent.

As expected, the two dependent variables were highly intercorrelated $(r=.44)$ showing that self-confidence and leadership ambition are closely related. This is a well-established finding in the leadership literature (Pendleton \& Furnham, 2017) and probably represents reciprocal causation: self-confident people are more likely to be chosen as leaders and being in a position of leadership increases self-confidence as defined by self-ratings of leadership potential.

The results showed that all six HPTI traits were positively and significantly associated with particularly risk approach (Courage) and Conscientiousness. If 


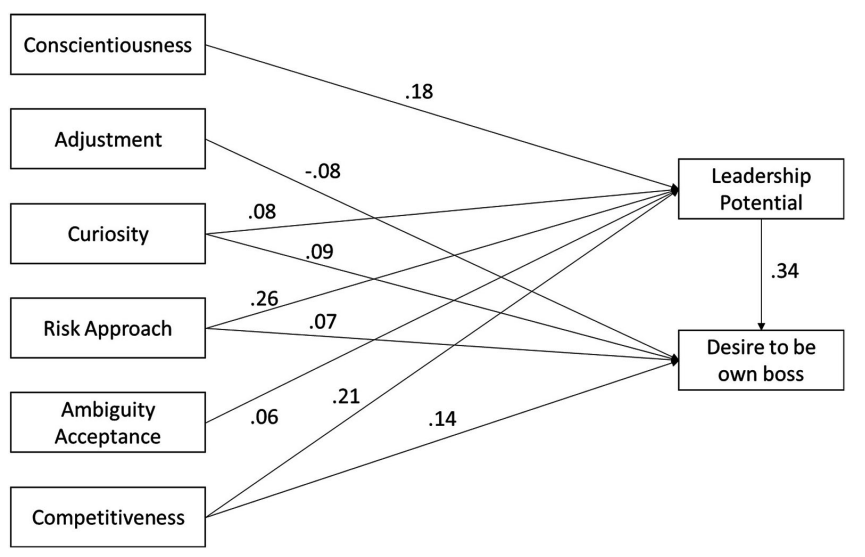

Figure 1. Structural equation model analysing multivariate relationships between HPTI, leadership potential, and desire to be own boss.

people are sufficiently insightful and accurate about the leadership potential this could be seen as validity evidence supporting this measure. Correlations between the six HPTI traits and desire to be your own boss were all positive but much lower than for the evaluation of leadership potential.

The literature on leadership supports these self-rated findings. Conscientious and Competitive people strive for leadership positions, their preferences and talents are recognised, and they tend to succeed in leadership roles (Hermans, 2007; Ng et al., 2005).

The regression showed that the six factors accounted for a third of the variance with respect to self-ratings of leadership potential. Competitiveness, Risk Approach and Conscientiousness were highly significant and only Adjustment was not. The regression for Be Your Own Boss showed that the traits accounted for only $15 \%$ of the variance (less than half than for leadership potential) but that when Leadership potential ratings were added an additional $8 \%$ of the variance was accounted for. Presumably those who feel they have leadership potential feel they could succeed in the role and become their own boss.

However, it is the SEM results which help to explain the process much better. Three traits, shown in previous studies to be related to management success, namely Curiosity, Competitiveness and Risk Approach (Courage) were related to both ratings (Teodorescu et al., 2017). The second highest loading indicated that Conscientiousness was related to ratings of Leadership effectiveness but not the Desire to be one's own boss. Presumably the participants had some idea of what has been found many times, namely that the facets of Conscientiousness namely being ordered, reliable, planful and hard-working are strong predictors of work success.

It was interesting to note that Adjustment was negatively related to the desire to be one's own boss. This implies that people prone to worry and stress (i.e. Neuroticism) are more likely to want to work for themselves or be in charge presumably because they believe they will be under less stress and pressure, though this is unlikely to be the case. The literature on leadership supports this 
finding: those more prone to acute and chronic stress, which are the markers of low Adjustment neither seek out, nor get selected to leadership roles; and if they do they rarely succeed. Interestingly, adjustment was not related to self-rated leadership but only desire to be your own boss.

Similarly, ambiguity tolerance was related to self-rated leadership potential. The ability to tolerate uncertainty is a requirement for senior management. We know that it is a marker of success in business and a correlate of other variables related to success (Furnham \& Marks, 2013).

There various implications of this study: first, as one might expect working adults do have some insight into their leadership potential; second Courage, Competitive, Conscientiousness and Curiosity are all related to both the desire to be a leader and success in leadership; third, these traits are easy and important to measure in candidates for leadership positions.

\section{Limitations}

Like all studies this had limitations. First, the data was predominantly self-report and the results could have been inflated by method invariance. It would have been better to get observer reports or behavioural history data of actual leadership experience and success. Also, it is acknowledged that the "desire to be your own boss" is somewhat ambiguous and not necessarily the same as the desire to be a leader. Thus, a highly introverted person may wish to work for themselves and hence "be their own boss". Equally consultants who are "one-man bands" work from themselves. From a pilot study asking 20 people what the phrase meant however, all mentioned that they were a leader. However, we perhaps should have asked people about their desire to become a leader as well as specifying in which domain: i.e. a business, a sports team etc.

\section{Conflicts of Interest}

The authors declare no conflicts of interest regarding the publication of this paper.

\section{References}

Archer, T., Arntén, A. C., Olsen, K., \& Jansson, B. (2016). Age and Gender Influence upon Self-Reported Leadership Attributes during Recruitment. Clinical and Experimental Psychology, 2, 15-17. https://doi.org/10.4172/2471-2701.1000140

Barrick, M. R., Mount, M. K., \& Judge, T. A. (2001). Personality and Performance at the Beginning of the New Millennium: What Do We Know and Where Do We Go Next? International Journal of Selection and Assessment, 9, 9-30. https://doi.org/10.1111/1468-2389.00160

Costa, P. T., \& McCrae, R. R. (1992). Revised NEO Personality Inventory (NEO-PI-R) and NEO Five-Factor Inventory (NEO-FFI) Professional Manual. Psychological Assessment Resources.

Furnham, A., \& Treglown, L. (2018). High Potential Personality and Intelligence. Personality and Individual Differences, 128, 81-87.

https://doi.org/10.1016/j.paid.2018.02.025 
Furnham, A. (2001). Self-Estimates of Intelligence: Culture and Gender Difference in Self and Other Estimates of Both General $(g)$ and Multiple Intelligences. Personality and Individual Differences, 31, 1381-1405. https://doi.org/10.1016/S0191-8869(00)00232-4

Furnham, A. (2018). Personality and Occupational Success. In V. Zeigler-Hill, \& T. K. Shackelford (Eds.), The SAGE Handbook of Personality and Individual Differences (pp. 537-551). New York: Sage Publications. https://doi.org/10.4135/9781526451248.n23

Furnham, A., \& Ribchester, T. (1995). Tolerance of Ambiguity: A Review of the Concept, Its Measurement and Applications. Current Psychology, 14, 179-199. https://doi.org/10.1007/BF02686907

Furnham, A., \& Marks, J. (2013). Tolerance of Ambiguity: A Review of the Recent Literature. Psychology, 4, 717. https://doi.org/10.4236/psych.2013.49102

Hannah, S. T., Sweeney, P. J., \& Lester, P. B. (2007). Toward a Courageous Mindset: The Subjective Act and Experience of Courage. The Journal of Positive Psychology, 2, 129-135. https://doi.org/10.1080/17439760701228854

Herman, J. L., Stevens, M. J., Bird, A., Mendenhall, M., \& Oddou, G. (2010). The Tolerance for Ambiguity Scale: Towards a More Refined Measure for International Management Research. International Journal of Intercultural Relations, 34, 58-65. https://doi.org/10.1016/j.ijintrel.2009.09.004

Hermans, J. (2007). High Potentials: A CEO Perspective. Journal of Studies in International Education, 11, 510-521. https://doi.org/10.1177/1028315307304187

Hooper, D., Coughlan, J., \& Mullen, M. R. (2008). Structural Equation Modelling: Guidelines for Determining Model Fit. Electronic Journal of Business Research Methods, 6, 53-60.

Hu, L. T., \& Bentler, P. M. (1998). Fit Indices in Covariance Structure Modeling: Sensitivity to under Parameterized Model Misspecification. Psychological Methods, 3, 424-453. https://doi.org/10.1037/1082-989X.3.4.424

Judge, T. A., \& Locke, E. A. (1993). The Effect of Dysfunctional Thought Processes on Subjective Well-Being and Job Satisfaction. Journal of Applied Psychology, 78, 475-490. https://doi.org/10.1037/0021-9010.78.3.475

Judge, T. A., Higgins, C. A., Thoresen, C. J., \& Barrick, M. R. (1999). The Big Five Personality Traits, General Mental Ability, and Career Success across the Lifespan. Personnel Psychology, 52, 621-652. https://doi.org/10.1111/j.1744-6570.1999.tb00174.x

Judge, T. A., Martocchio, J. J., \& Thoresen, C. J. (1997). Five-Factor Model of Personality and Employee Absence. Journal of Applied Psychology, 82, 745-755.

https://doi.org/10.1037/0021-9010.82.5.745

Kline, R. B. (2005). Principles and Practices of Structural Equations Modelling. New York: Guildford Press.

MacCallum, R. C., Browne, M. W., \& Sugawara, H. M. (1996). Power Analysis and Determination of Sample Size for Covariance Structure Modeling. Psychological Methods, 1, 130-149. https://doi.org/10.1037/1082-989X.1.2.130

MacRae, I. (2012). An Psychometric Analysis of a High Potential Measure. Unpublished Master's Thesis, London: University College.

MacRae, I., \& Furnham, A. (2014). High Potential: How to Spot Manage and Develop Talented People at Work. London: Bloomsbury Publishing.

McCall, M. W. (1997). High-Flyers: Developing the Next Generation of Leaders. Boston, MA: Harvard Business School.

McClelland, D. C. (1965). Achievement and Entrepreneurship: A Longitudinal Study. 
Journal of Personality and Social Psychology, 1, 389-392.

https://doi.org/10.1037/h0021956

Moore, L. L., \& Rudd, R. D. (2005). Extension Leaders' Self-Evaluation of Leadership Skill Area. Journal of Agricultural Education, 46, 68-78. https://www.researchgate.net/profile/Rick_Rudd/publication/228345249_Extension_Le aders'_SelfEvaluation_Of_Leadership_Skill_Areas/links/54b91a440cf28faced626dcc.pdf https://doi.org/10.5032/jae.2005.01068

Ng, T. W. H., Eby, L. T., Sorensen, K. L., \& Feldman, D. C. (2005). Predictors of Objective and Subjective Career Success: A Meta-Analysis. Personnel Psychology, 58, 367-408. https://doi.org/10.1111/j.1744-6570.2005.00515.x

Norton, P. J., \& Weiss, B. J. (2009). The Role of Courage on Behavioral Approach in a Fear-Eliciting Situation: A Proof-of-Concept Pilot Study. Journal of Anxiety Disorders, 23, 212-217. https://doi.org/10.1016/j.janxdis.2008.07.002

Pendleton, D., \& Furnham, A. (2017). Leadership: Everything You Want to Know. London: Palgrave McMillan.

Rosseel, Y. (2012). Lavaan: An R Package for Structural Equation Modeling and More Version 0.5-12 (BETA). Journal of Statistical Software, 48, 1-36. https://users.ugent.be/ yrosseel/lavaan/lavaanIntroduction.pdf https://doi.org/10.18637/jss.v048.i02

Teodorescu, A., Furnham, A., \& Macrae, I. (2017). Trait Correlates of Success at Work. International Journal of Selection and Assessment, 25, 36-42. https://doi.org/10.1111/ijsa.12158

Thornton, B., Ryckman, R. M., \& Gold, J. A. (2011). Competitive Orientations and the Type A Behavior Pattern. Psychology, 2, 411-415. https://doi.org/10.4236/psych.2011.25064

van Dam, K. (2015). Workplace Goal Orientation. European Journal of Psychological Assessment, 31, 62-68. https://doi.org/10.1027/1015-5759/a000207

Van der Linden, D., Scholte, R. H., Cillessen, A. H., Nijenhuis, J., \& Segers, E. (2010). Classroom Ratings of Likeability and Popularity Are Related to the Big Five and the General Factor of Personality. Journal of Research in Personality, 44, 669-672. https://doi.org/10.1016/j.jrp.2010.08.007

Wang, G., \& Netemeyer, R. G. (2002). The Effects of Job Autonomy, Customer Demandingness, and Trait Competitiveness on Salesperson Learning, Self-Efficacy, and Performance. Journal of the Academy of Marketing Science, 30, 217-228. https://doi.org/10.1177/0092070302303003

Wille, B., De Fruyt, F., \& Feys, M. (2013). Big Five Traits and Intrinsic Success in the New Career Era: A 15-Year Longitudinal Study on Employability and Work-Family Conflict. Applied Psychology, 62, 124-156.

https://doi.org/10.1111/j.1464-0597.2012.00516.x 